\title{
THE ACTIVITIES OF GOT, GAMMA-GT, ALKALINE PHOSPhATASE IN BLOOD PLASMA OF COWS AND THEIR CALVES FED FROM BUCKETS
}

\author{
J. BOUDA, V. DVOŘ́Á, E. MINKSOVÁ, R. DVOŘ́K \\ Department of Diagnostics, Therapy and Prophylaxis of Animal Diseases, \\ University of Veterinary Science, 61242 Brno
}

Dedicated to the 50th birthday of prof. P. Jagoš, CSc.

Received fanuary 26, 1979

\begin{abstract}
Bouda J., V. Dvořák, E. Minksová, R. Dvořák: The Activities of GOT, Gamma-GT, Alkaline Phosphatase in Blood Plasma of Cows and Their Calves Fed from Buckets. Acta vet. Brno, 49, 1980: 193-198.

The activities of GOT, gamma-GT and alkaline phosphatase (AP) were followed in blood plasma of 40 late pregnant cows and their calves until the age of three months. The mean value of GOT activities in pre-partum cows was found to be lower than in post-partum ones, whereas in the case of AP this was reversed. No significant differences were observed in gamma-GT activities in pre- and post-partum cows but in both groups the activities were increased in more than $30 \%$ of animals.

The average values of GOT activities in calves did not exceed $30 \mathrm{U} / 1$, only at the age of two months the activities were found to be raised over $46 \mathrm{U} / \mathrm{l}$. The gamma-GT activities in calves aged up to two months were significantly higher $(P<0.01)$ than those found in their dams. 24 hours after the first colostrum intake the gamma-GT activity increased 16 times compared with that before the colostrum intake. The highest mean AP activity in calves appeared 24 hours past the colostrum intake although at the age of three months it was still two times higher than in their dams.

The activities of plasmatic enzymes were determined in dependence on calf age which can be applied as reference values in diagnostics of some diseases.
\end{abstract}

Cow, calf, blood plasma, enzymes, GOT, gamma-glutamyltranspeptidase (gamma-GT), alkaline phosphatase $(A P)$, metabolism.

The determination of plasmatic enzyme activities assumes an important place in laboratory diagnostics. When selecting the enzyme activity determination in clinico-biochemical laboratory the organ specifity, the sensitivity of reaction to organ damage, the precision and rapidity of examination have to be observed. For example, it has been known for a long time that GTP, used in diagnostics of liver disorders in man and small animals, is almost useless in cattle (Gründer 1961; Gerber et al. 1973; Bouda et al. 1977).

To evaluate pathological values it is necessary to know first the reference values of enzyme activities. These standards are, however, valid only for a given method being also dependent on animal age, sex, performance, reproduction stage and nutrition (Sommer 1970; Jagoš et al. 1975). The knowledge of diurnal dynamics of individual enzyme activities is also important. It follows from the work of Hagemeister and Unsheelm (1968) that the activities of GOT, alkaline phosphatase (AP), GPT do not change substantially during the day whereas the LDH activity reaches the lowest value at $8 \mathrm{a} . \mathrm{m}$., not changing significantly between $10 \mathrm{a} . \mathrm{m}$. and $6 \mathrm{p} . \mathrm{m}$.

The significance of enzyme diagnostics in veterinary medicine, predominantly in catttle, consists mainly in diagnostics and differential diagnostics and also in prognostic evaluation of liver and skeletal muscle damage (Bouda et al. 1977). 
The utmost attention both in human and veterinary medicine has been paid to transaminases. Under normal conditions small amount of GOT transfers to blood plasma without performing any function there. GOT is found in cells of various organs, predominantly in liver and muscle. The determination of this enzyme has good application possibilities in diagnostics of liver disorders although GOT could be increased also in other diseases (Sommer 1970).

The mean values of GOT activities in calf plasma were found to vary from 0.99 to $2.03 \mu \mathrm{mol} / 1 \mathrm{ml}$, in some samplings from 0.40 to $3.30 \mu \mathrm{mol} / 1 \mathrm{ml}$ (Surynek et al. 1975). The normal value of GOT activity in cow blood plasma does not exceed $1.8 \mu \mathrm{mol} / \mathrm{l} \mathrm{ml}$ (Jagoš et al. 1975). Previously used units of enzyme activities (in $\mu \mathrm{mol} / \mathrm{ml}$ ) could be changed to international units (U/l) by multiplication of $\mu \mathrm{mol} / \mathrm{ml}$ by the factor 16.7 .

Alkaline phosphatase (AP) is contained in almost all tissues, mostly in intestinal mucosa, liver and bone. As for calf blood plasma the highest values were recorded in the first weeks of life (Manteuffel 1975; Surynek et al. 1975). The physiological activity in blood plasma does not exceed $50 \mathrm{U} / 1$ (Jagoš et al. 1975).

The highest attention from the point of view of liver disorder diagnostics has been recently paid to gamma-glutamyltranspeptidase (gamma-GT) (Findeisen 1972; Bouda et al. 1977; Keller 1978; Gründer 1976). When using Boehringer test the gamma-GT activity in blood serum of healthy cows did not exceed $16.2 \mathrm{U} / \mathrm{l}$ and was not found to be increased even in pathological processes in kidneys (Keller 1978). Blackshaw (1978) arrived at the same conclusion, reporting the value of $2-20 \mathrm{U} / \mathrm{l}$ as being normal for cattle.

The gamma-GT activity does not change even during pregnancy. The mean value of gamma-GT activity in blood serum was found to be 10.7 and $15.1 \mathrm{U} / 1$ in calves and heifers, resp. and from the diagnostics point of view it is more valuable than GOT and bilirubin data (Findeisen 1972).

\section{Materials and Methods}

The experiment was conducted on $\mathbf{4 0}$ late pregnant cows and their $\mathbf{4 2}$ calves of Czech Spotted breed in a large-capacity cow house accomodating 600 animals. The clinical examination and blood sampling of cows was carried out 2-5 weeks prior to expected date of parturition and 2-4 weeks post partum. At the same time urine samples were taken by catheterization and the average sample of colostrum from the first milking was collected from cows.

Immediately after birth calves were transferred into individual cages in a separated calfhouse, at the age of 14-18 days moved into another calf-house. Twice a day the calves were given colostrum from buckets and from the sixth day the calves were turned to a milk-replacer Laktosan $\mathrm{A}$. The daily colostrum ration was 4-5 litres, that of milk-replacer Laktosan A 6-7 litres. The TK-1 mixture (concentrate) for calves was supplemented from the 1lth day, meadow hay from three weeks of calf age. The mean weight of calves prior to colostrum intake was $42.2 \mathrm{~kg}$. The health condition of calves was followed from birth to the age of 3 months. The blood samples were taken from $v$. jugularis prior to colostrum intake and then after 1, 3, 7, 21, 42, 56 and 84 days past the colostrum intake.

The activities of GOT, AP, gamma-glutamyltranspeptidase in blood plasma were determined photometrically on the Eppendorf instrument using the Bio-test kit (Lachema Brno).

The results obtained were evaluated on a Hewlett-Packard computer, 9810 A Model. To test the difference between individual samplings the method of simple split analysis and Duncan's test were used.

\section{Results}

The values of GOT, AP and gamma-GT activities in cow blood plasma preand post-parturition are given in Table 1 . The mean value of GOT activity in pre-partum cows was found to be lower than that in postpartum cows. On the other hand, the value of AP activity was significantly higher in prepartum cows. There were no significant differences in gamma-GT activities between pre- and postpartum cows; it is, however, necessary to add that both in prepartum and postpartum cows the gamma-GT activity was found to be raised above standard in approximately $30 \%$ of animals.

The dynamics of mean GOT, gamma-GT and AP activities in calf blood plasma in dependence on age is presented in Table 2. The mean values of GOT activities 
Table 1

The mean activities of GOT, AP and gamma-GT in blood plasma of pre- and postpartum cows

\begin{tabular}{|l|c|c|c|}
\hline \multicolumn{1}{|c|}{ Followed index } & Prepartum cows & Postpartum cows & P \\
\hline GOT (U/1) & $18.8 \pm 3.4$ & $27.1 \pm 5.5$ & ++ \\
AP (U/1) & $64.4 \pm 22.0$ & $46.3 \pm 29.9$ & ++ \\
gamma-GT (U/l) & $32.1 \pm 6.8$ & $29.2 \pm 9.1$ & - \\
\hline
\end{tabular}

$\mathbf{P}<0.01=++$

$\mathbf{P}>0.05=-$

Table 2

The mean enzyme activities (GOT, gamma-GT, AP) in blood plasma

\begin{tabular}{|c|c|c|c|c|c|c|c|}
\hline \multirow{2}{*}{ Animal } & \multirow{2}{*}{$\underset{\text { (days) }}{\text { Age }}$} & \multicolumn{2}{|c|}{ GOT (U/1) } & \multicolumn{2}{|c|}{ Gamma-GT (U/1) } & \multicolumn{2}{|c|}{ AP $(U / 1)$} \\
\hline & & $\overline{\boldsymbol{x}}$ & $\boldsymbol{s}$ & $\bar{x}$ & $s$ & $\bar{x}$ & $s$ \\
\hline $\begin{array}{l}\text { Cows } \\
\text { Calves }\end{array}$ & $\begin{array}{l}\text { Prepartum } \\
\text { Without }\end{array}$ & $\begin{array}{l}18.8 \\
11.1\end{array}$ & $\begin{array}{l}3.4 \\
4.1\end{array}$ & $\begin{array}{l}32.1 \\
92.4\end{array}$ & $\begin{array}{r}6.3 \\
52.1\end{array}$ & $\begin{array}{r}64.4 \\
163.6\end{array}$ & $\begin{array}{l}22.0 \\
52.2\end{array}$ \\
\hline & $\begin{array}{c}1 \\
3 \\
5-7 \\
14 \\
21 \\
42 \\
56 \\
84\end{array}$ & $\begin{array}{l}17.5 \\
10.1 \\
10.9 \\
12.4 \\
15.3 \\
25.1 \\
36.7 \\
24.3\end{array}$ & $\begin{array}{r}5.2 \\
3.5 \\
4.4 \\
4.3 \\
5.9 \\
7.2 \\
32.9 \\
8.5\end{array}$ & $\begin{array}{r}1523.0 \\
535.4 \\
367.1 \\
155.9 \\
87.1 \\
42.7 \\
54.8 \\
33.9\end{array}$ & $\begin{array}{r}1356.5 \\
415.6 \\
323.6 \\
153.2 \\
65.1 \\
18.6 \\
31.6 \\
9.9\end{array}$ & $\begin{array}{l}334.3 \\
190.1 \\
167.2 \\
112.3 \\
152.1 \\
121.2 \\
113.8 \\
124.8\end{array}$ & $\begin{array}{r}210.0 \\
60.4 \\
76.3 \\
38.0 \\
55.4 \\
40.0 \\
32.5 \\
33.2\end{array}$ \\
\hline
\end{tabular}

during the whole experiment did not exceed $30 \mathrm{U} / 1$, the only exception being the increase above $36 \mathrm{U} / 1$ in the case of calves aged 2 months. At the age of 6 weeks and 2 months the GOT activity was found to be exceeding the reference value in almost $30 \%$ of the total number of followed animals.

Great differences occurred in calf gamma-GT activities, which were found to be significantly higher in calves up to the age of 2 months than those in cows $(P<0.01)$. The greatest differences in gamma-GT activities were observed in calves in the first days of their lives. The gamma-GT activities increased more than 16 times after 24 hours after the first colostrum intake compared with the values obtained prior to colostrum intake. In calves aged 3 days the gamma-GT activities reached only one third of the maximal value in the first day. With the increasing age of calves the gamma-GT activities were found to be slowly decreasing and at the age of 3 months they were identical with those of cows.

It is evident from the AP values that the highest mean activity was determined 24 hours after the first colostrum intake. In the following days the AP activity slowly dropped. The dynamics of AP activity in dependence on calf age is, to a certain extent, similar to gamma-GT changes which were, however, more pronounced. From the second week of age up to three months the AP activities remained in a relatively narrow range, being, however, two times higher than in their dams. 


\section{Discussion}

When evaluating mean activities of GOT, and AP in blood plasma of preand postpartum cows statistically significant differences were found. The mean GOT and AP values were within range of reference values determined by the system of preventive diagnostics worked out by Jagoš et al. (1975). The individual GOT values were found to be increased above standard in one third of cows, only in the postpartum period. GOT is not considered to be a specific enzyme but its activity raises, according to Sommer (1970), in impaired liver and muscle function.

The increased gamma-GT activities in pre- and postpartum cows, found in more than $30 \%$ of animals, without more pronounced painfulness, presented a more valuable finding for us. This enzyme is, according to Gründer (1976) and Keller 1978) a specific indicator of liver damage. In our experiments the value below $30 \mathrm{U} / 1$ was considered to be normal in contrast to many other authors (Findeisen 1972; Gründer 1976; Keller 1978) reporting lower values. The mentioned authors used, however, a different test and when comparing the Boehring test with our Bio-test (Lachema) we found that the gamma-GT activities determined by Bio-test (Lachema) had been by $48 \%$ higher.

The interrelations between GOT and AP activities in cows and calves prior to colostrum intake were found to be similar as those described between dams and calf foetuses. Significantly higher differences were observed in gamma-GT between cow and calf where the value in calves already prior to colostrum intake was three times higher than in their dams, whereas the activities in calf foetuses were approximately by one half lower than those in their dams (Bouda, Jagoš 1979).

Upon the colostrum intake the GOT, and predominantly gamma-GT, activities increased. The highest GOT activities were observed in calves aged 8 weeks, i. e. in the period of most frequent occurrence of muscle dystrophy when no symptoms may be found by clinical examination (Kursa et al. 1969). Thus this enzyme may well be used in muscle dystrophy diagnostics.

The most marked changes were observed in the activity of plasmatic gamma-GT which especially in calves after colostrum intake increased approximately 16 times and then slowly fell so that at the age of 3 months it did not differ significantly from that of cows. Since the gamma-GT enzyme is considered as being specific for liver disorders the increase of its activity could be connected with the raised liver activity in calves after birth. It is interesting that the activity of this enzyme increased markedly already three hours after the colostrum intake. The whole problem appears to be more complex and even the influence of the first colostrum gamma-globulins intake cannot be excluded.

\section{Aktivity enzymů GOT, gama-GT, alkalické fosfatázy v krevní plazmě krav a jejich telat napájených $\mathrm{z}$ nádob}

V krevní plazmě 40 vysokobřezích krav a jejich telat do stáŕi 3 měsíců byly studovány aktivity GOT, gamma-GT a alkalické fosfatázy (AP). Průměrná hodnota aktivit GOT u krav před porodem byla nižší než po porodu, obráceně tomu bylo u AP. V aktivitách gama-GT nebylo významných rozdílů u krav před a po porodu, ale u obou skupin byly zvýšeny aktivity víc jak u $30 \%$ zviŕat. 
Průměrné hodnoty aktivit GOT nepřesáhly u telat $30 \mathrm{U} / 1$, pouze ve stáří 2 měsíců byly aktivity zvýšeny nad $46 \mathrm{U} / 1$. Aktivity gama-GT u telat do stáŕí 2 měsíců byly významně vyšši $(P<0,01)$ než u jejich krav. $Z a$ 24 hodin od př́ijmu prvé dávky kolostra stoupla aktivita gama-GT 16krát ve srovnání $s$ aktivitou před prŕijmem kolostra. Nejvyšší průměrná aktvita $\mathrm{AP}$ u telat byla 24 hodin po přímu kolostra, avšak ve stáří 3 měsíců byla stále 2 krát vyšší než u jejich matek.

Byly stanoveny aktivity plazmatických enzymů $\mathrm{v}$ závislosti na stárí telat, kterých lze použít jako referenčních hodnot pro diagnostiku některých onemocnění.

\section{Активности энзимов глутамат-оксальацетат-трансаминазы (GOT), гамма-глутамилтранспептидазы гамма-(GT), щелочной фосфатазы в кровяной плазме коров и их телят, поенных из сосудов}

В кровяной плазме 40 коров высокой беременности и их телят в возрасте до 3 месяцев проводились исследования активности GOT, гамма-GT и щелочной фосфатазы. Средняя величина активности GOT коров перед отелом находилась ниже величины после отела; наоборот обстояло дело в случае щелочной фосфатазы. В активностях гамма-GT не наблюдалось существенных различий у коров до и после отела, однако, у обеих групп имело место повышение активности более чем $30 \%$ животных.

Средние величины активностей ГОТ не превышали у телят 30/л, лишь в возрасте 2 месяцев активности превышали 36/л. Активности гамма-GT телят в возрасте до 2 месяцев были значимо выше $(\mathrm{P}<0,01)$ по сравнению с их матками. Активность гамма-GT в течение суток со времени приема молозива поднялась в 16 раз по сравнению с активностью до приема молозива. Максимальная средняя активность щелочной фосфатазы наблюдалась сутки после приема молозива, однако, в возрасте 3 месяцев она была 2 раза выше активности их маток.

Определялись активности плазматических энзимов в зависимости от возраста телят, которые можно использовать в качестве сравнимых величин с целью диагностики некоторых заболеваний.

\section{References}

BLACKSHAW, C.: Serum gamma-glutamyltransferase in the diagnosis of liver diseases in cattle. New Zealand Vet., 26, 1978: 16, 25-26.

BOUDA, J. - JAGOŠ, P. - DVOŘÁK, R. - PISKAČ, A.: Změny v aktivitě enzymů při experimentální aflatoxikóze dojnic. Vet. Med. (Praha), 22, 1977: 137-142.

BOUDA, J. - JAGOŠ, P.: Bílkoviny a aktivity enzymů v krvi vysokobřezích krav a jejich fétů. Acta Vet. Brno, 48, 1979, in press.

FINDEISEN, R.: Untersuchungen über die Aktivität der gamma-Glutamyltranspeptidase im Serum gesunder und kranker Rinder. Thesis Tierärztliche Hochschule Hannover, 1972, 60 pp.

GERBER, H. - MARTIG, J. - STRAUB, R.: Enzymuntersuchungen im Serum von Grosstieren im Hinblick auf Diagnose und Prognose. Tierärztl. Prax., 1, 1973: 5-18.

GRÚNDER, H. D.: Der diagnostische Wert einiger Leberuntersuchungsmethoden beim Rind unter besonderer Berüchsichtigung der Serumtransaminasebestimmung. Dtsch. Tierärztl. Wschr., 68, 1961: 677-682.

GRÚNDER, H. D.: Die diagnostische Bedeutung einiger Serumfermente (CPK, gama-GT, GLDH, ICDH). beim Rind. 9. mezinárodní kongres o chorobách skotu, Par̆́iž 9. - 9. 9. 1976.

HAGEMEISTER, H. - UNSHELM, J.: Individuelle, tages und tagesgeitabhängige Schwan kungen von Blutbestandteilen beim Rind. 2. Mitteilung: Das Verhalten der Enzymaktivität von GOT, GPT, LDH, MDH, GLDH und alkalische Phosphatase. Zbl. Vet. Med., A, 15, 1968: $499-509$. 
JAGOS, P. - BOUDA, J. - ILLEK, J. - HOFÍREK, B.: Rozpracování metabolických testú $\mathrm{k}$ určení skrytých poruch výměny látkové $\mathrm{u}$ dojnic $\mathrm{v}$ podmínkách prủmyslových komplexú. Project Report, University of Veterinary Science, Brno 1975, 50 pp.

KELLER, H.: GLDH und gamma-GT Aktivitäter im Serum gesunder und Lebergelbefallener Rinder. Schweiz. Arch. Tierheilk., 120, 1978: 189-193.

KURSA, J.: Nutriční svalová degenerace u mladého skotu v distriktu Šumavy. Vet. Med. (Praha), 14, 1969: 549-559.

MANTEUFFEL, U. V.: Untersuchungen über den Einfluss der Alters und der Fütterung auf die alkalische und säure Phosphatase im Bluttserum von Kälbern. Zbl. Vet. Med., 22, 1975: $209-214$.

SOMMER, H.: Zur Überwachung der Gesundheit des Rindes mit Hilfe klinisch-chemischer Untersuchungsmethoden. Arch. Exper. Vet. Med., 24, 1970: 735-776.

SURYNEK, J. - KUČERA, A. - JANU゚, J. - HOJOVCOVÁ, M.: Sledování některých základních ukazatelů biomedicinského profilu telete $\mathrm{v}$ postnatálním údobí. Project report, University of Veterinary Science, Brno, 1975, 78 pp. 